Eric B Niyitunga

Senior Lecturer and Researcher, School of Leadership, Soweto Campus, Faculty of Management, University of Johannesburg. niblanceric@gmail.com / ericn@uj.ac.za

DOI: https://dx.doi.org/ 10.18820/24150509/ JCH41.v2.12

ISSN 0258-2422 (Print) ISSN 2415-0509 (Online)

Journal for Contemporary History 2016 41(2):229-250

(C) UV/UFS

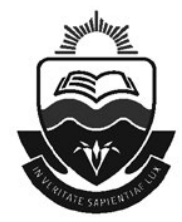

\section{ASSESSING THE MISSING LINK WITHIN THE CONCEPT OF PREVENTIVE DIPLOMACY WITH REFERENCE TO AFRICAN CONFLICTS}

\begin{abstract}
The role of preventive diplomacy is to prevent the emergence of violent conflicts, to prevent on-going conflicts from spreading and to prevent the relapse of an already settled conflict. The purpose of this article is to critically assess the existing gaps within the concept of preventive diplomacy that render it less appropriate in preventing and managing African conflicts in the post-Cold War era. The article gives an overview of the historical development of preventive diplomacy, referred to as orthodox preventive diplomacy. It examines the existent missing link within the concept of orthodox preventive diplomacy, and explains why the concept was ineffective in resolving African conflicts and preventing their recurrence. In conclusion, it is asserted that, given the fact that both the character and the agents of conflicts changed from interstate to intrastate, a new preventive diplomacy is needed to successfully prevent deadly conflicts before they occur. A qualitative research method, with an exploratory approach, was adopted.
\end{abstract}

Keywords: African conflicts; conflict management; orthodox preventive diplomacy; new preventive diplomacy; nature and components of new preventive diplomacy; post-Cold War.

Sleutelwoorde: Afrika-konflikte; konflikhantering; ortodokse voorkomende diplomasie; nuwe voorkomende dilomasie; aard en samestelling van voorkomende diplomasie; post-Koue Oorlog.

\section{INTRODUCTION}

The writing of this article was, to a large degree, influenced by the prevalence of African conflicts and the threats these conflicts pose to international peace and security in the sense that, what affects one state, affects the others as well. The significance of preventing violent conflicts became a subject of interest at the end of the Cold War. According to Jentleson (1996:3-5), cases, such as the genocide in Rwanda, and the ethnic wars in Burundi, the Democratic Republic of the Congo and Bosnia-Herzegovina, as well as state failure in Somalia in the 1990s and early 2000s, point 
to the need to find means to prevent conflicts from escalating into war, human disasters and regional instability. Preventive diplomacy, as one of the means of preventing violent conflicts, is needed more than ever to prevent African conflicts, and to help fragile governments in building strong institutions that can ensure democratic governance. In a report, the former United Nations (UN) SecretaryGeneral, Boutros Boutros-Ghali (1992:18) illustrates that preventive diplomacy implies the use of any diplomatic means to resolve violent conflicts and to prevent them from re-emerging in the future. Similarly, Kofi Annan (2005:7) argues that, if states and their leaders take preventive diplomacy more seriously, it would help to ensure that there are fewer conflicts and civil wars. He also argues that, "applying preventive diplomacy efforts to resolve and prevent the re-emergence of internal violence would save not only tens of billions of dollars, but also hundreds of thousands of lives" (Annan 2005:8).

One of the major factors that led to the prevalence of African conflicts is the failure to recognise the existent missing link within the concept of preventive diplomacy. This missing link is by and large caused by the changing character of modern conflicts. Another factor that has failed in resolving and preventing African conflicts is the inability of the African Union (AU)'s peace practitioners and mediators to understand this missing link when engaged in diplomatic negotiations on the continent. A study conducted by MK Cahill (2000:31) notes that peoples, nations, organisations, and public opinion are only slowly, too slowly, becoming aware of this missing link; which is why preventive diplomacy experience failures in today's conflict management.

The central question this article sets out to answer is: why does preventive diplomacy, as applied by the AU diplomats to African conflicts, fail to successfully bring about positive change and what could be the missing link within the concept that leads to such a failure? In other words, that which makes the management of African conflicts and their prevention unachievable is that these conflicts continue to pose major threats to regional and international peace and security. This research asserts that preventive diplomacy is important, not only in Africa, but also in world politics. If well applied by skilled diplomats, and its components maintained, this diplomacy has the ability to resolve conflicts at their root causes and prevent their recurrence. Hence, the overarching aim of this article is to critically assess the missing link within the concept of preventive diplomacy that rendered it inappropriate in the post-Cold War era, especially with regard to African conflicts.

To conceptualise the arguments, the article is structured into three main sections. In the first section, an overview is given of the historical development of the concept of preventive diplomacy, namely orthodox preventive diplomacy, from the time of the Concert of Europe to the current United Nations Organisation (UN). Secondly, the existent missing link that has by and large made the concept of orthodox preventive diplomacy inappropriate to African conflicts is assessed. 
Thirdly, a working definition of the new preventive diplomacy is offered and the elements that make the concept appropriate in resolving and preventing African conflicts are discussed. In the concluding section, it is asserted that there is a need for a paradigm shift from orthodox preventive diplomacy to the new preventive diplomacy. The latter has a significant role to stop conflicts from spilling over into wars, as well as in preventing them from re-emerging on the continent.

\section{THE HISTORICAL DEVELOPMENT OF ORTHODOX PREVENTIVE DIPLOMACY}

The fall of the Berlin Wall in 1989 symbolised the end of the Cold War as an ideological battle between the Western and Eastern blocs. This confrontation impacted on the African continent in the emergence of proxy wars and the destruction of African traditional methods of dealing with conflict before it turns into violence. Furthermore, the Cold War undermined African governments and prevented the evolution of local ideologies to address local issues from an African perspective. It is important to notice that, immediately after the end of the Cold War, the major security threats in Africa, more than ever, became intrastate wars without the involvement of Great Powers, largely characterised as ethnic and intercommunal conflict (Kaldor 2012:4). During this period the concept of orthodox preventive diplomacy, introduced by Boutros-Ghali in 1992, became widely known. Yet, the origins of this concept lie in the earlier idea of the Concert of Europe. This section will, therefore, examine the origins of the concept of orthodox preventive diplomacy and explain how it developed to become one of the current UN pillars for maintaining international peace and security.

Cahill (2000:30) points out that the concept of orthodox preventive diplomacy is not a new invention in the contemporary peace and security framework of the UN. Orthodox preventive diplomacy has always existed and has been used as one of the ways of resolving and mitigating violent conflicts in all human societies. L Woocher (2009:3) argues that the concept of orthodox preventive diplomacy, which entails that violent conflict can be resolved before it occurs, has been around for many generations and has taken on various forms. It can be argued that this concept originated in the early formal notions of preserving peace and preventing the occurrence of disputes among sovereign states in the system called the Concert of Europe, which was developed after the Congress of Vienna in 1815. The Hague Peace Conferences were also influenced by this concept. It was adopted by the League of Nations and later embraced by the UN in its peace and security framework (Ramcharan 2008:11).

R Elrod (1976:159-174) points out that the Concert of Europe consisted of mutual cooperation between the great and small powers of the time for the purpose of finding durable solutions to European problems of conflicts between and among states. This Concert originated during the Napoleonic Wars in 
Europe. It is essential to know that these wars were interstate in nature and the Concert was an attempt to resolve them by peaceful means and prevent the re-emergence of future conflicts between states, while also preserving the "legitimate" monarchical rule in leading states. It established frameworks that helped alleviate threats to international peace and security between sovereign states (Elrod 1976:159-174). B Ramcharan (2008:12) illustrates that, under the Concert of Europe, the ideas of orthodox preventive diplomacy were seen as a balance of power, which later became the mechanism that European sovereign states relied on to prevent any re-emergence of conflicts.

C Holbraad (1971) argues that the concept of preventing any disturbance of the balance of power was an instrument used to preserve and maintain international peace and security through the Concert of Europe. Furthermore, Elrod (1976: 159-174) notes that this idea of orthodox preventive diplomacy was translated into cooperation among European sovereign states to maintain postwar agreements. Therefore, the Concert of Europe followed the principle that, should any disputes arise between states, the use of good office and mediation should be given a chance before they resort to open fighting. It is in this Concert of Europe that the fundamental ideas of orthodox preventive diplomacy, that became prominent in the $21^{\text {st }}$ century, originated (Ramcharan 2008:10-11).

Ramcharan (2008:10; see also Branislav 2005:565-606) continues by arguing that the Congress of Vienna in 1815 laid down laws relating to war that gave birth to the Congress system. These laws were set to control war between sovereign states and prevent its future outbreak. The aim of the re-establishment of these laws was to prevent the occurrence of any wars or disputes among the states involved. The Congress created agreements between states that enabled leaders to cooperate among themselves, in order to uphold peace and stability. Ramcharan illustrates that the Congress established laws and regulations that helped promote peace, security and order within states, as well as between them. According to A Ackermann (2003:340) orthodox preventive diplomacy in the era of the Congress of Vienna also involved laws that helped create demilitarised zones and neutral states. This means that the concept of orthodox preventive diplomacy was expressed in the laws laid down by the Congress of Vienna and these laws played a major role in preventing the recurrence of violent wars in Europe.

Ramcharan (2008:13) contends that the concept of orthodox preventive diplomacy was later explicitly picked up at the Hague Peace Conferences in 1899 and 1907. During these conferences, it was agreed that both great and small states should respect customary laws, uphold international law and promote peaceful methods for settling disputes. In order to resolve and prevent conflicts between and among states, these conferences recommended the practice of mediation and arbitration, and the protection of civilians during war by upholding international laws of war that were codified and developed during 
these conferences. Thus, the Permanent Court of Arbitration and the Hague Provisions on the laws of war that reinforced orthodox preventive diplomacy originated from the Hague Peace Conferences (Ramcharan 2008:11-12). Higgins (2014:84) argues that the idea of orthodox preventive diplomacy was also made evident when the Hague Peace Conferences created and established the International Judicial Arbitration Court as an international institution assigned to settle and prevent any international disputes.

Orthodox preventive diplomacy gained strength when its concept on the peaceful settlement of international disputes was recorded in Article 2 of the Hague Convention. It was stated that sovereign states should make use of good office and mediation as an alternative before resorting to war (Ramcharan 2008:14). As an example, to a large extent, orthodox preventive diplomacy successfully prevented the outbreak of war between Britain and Russia over the Dogger Bank Affair in October 1904 (Higgins 2014:77). However, this concept in orthodox preventive diplomacy of resolving conflicts through peaceful means and preventing the re-emergence of warfare did not ultimately prevail, as it failed to prevent the outbreak of World War I. Nevertheless, it was retrieved after the damage wrought by the First World War and inserted into the Covenant of the League of Nations (Ramcharan 2008:12). Thus, orthodox preventive diplomacy found its way into the League of Nations.

Falk and Mendlovitz (1996:5) point out that the League of Nations was established immediately after the end of World War I in 1919 to avoid reemergence of war between sovereign states. Indeed, preventing the outbreak of conflicts became the fundamental concept of the League of Nations. It is important to know that the League was referred to as a union of sovereign states moved by the spirit of cooperation to maintain international peace and security among its member states. In order to uphold and maintain international peace and security, League members decided to set rules on disarmament that sought to limit states' armed forces (Ramcharan 2008:14).

The establishment of rules on disarmament by the League of Nations was an expression of the agency's commitment to the practice of orthodox preventive diplomacy as a vital way of preserving peace, security and stability among states. It was agreed that League members should resort to judicial settlement, rather than violence (Ramcharan 2008:14). Judicial settlement was the mechanism through which orthodox preventive diplomacy was exercised by the League member states in case of any probability of violent conflict among and/or between them. Thus, war was only allowed when this mechanism had failed. However, the League of Nations recommended that, during warfare, the protection of noncombatants through rules and the international laws and customs of wars agreed upon during the Hague Peace Conferences were to be upheld (Higgins 2014:88).

For instance, Ramcharan (2008:15) records that Eric Drummond, the then Secretary-General of the League, relied on preventive diplomacy, and through 
mediation he eventually prevented the dispute between Sweden and Finland over the Aaland Islands in 1921 from escalating into war. During the League of Nations era, the practice of preventive diplomacy was marked by success, as well as failures. But it miserably failed to consistently prevent war among states, a failure culminating in the outbreak of World War II which claimed the lives of millions. This failure saw the establishment of the UN with the mandate to maintain international peace and security, preventing future generations from suffering the scourges of wars. Thus, the concept of orthodox diplomacy found its way into the UN systems.

When the UN was formed after World War II in 1945, it took the torch of orthodox preventive diplomacy forward, and the concept became one of the pillars used to maintain international peace and security in today's world politics (Ramcharan 2008:16). As is well articulated in Chapter I, Chapter VI, Article 33 and Chapter VII of the UN Charter, parties agreed to work together to prevent the outbreak of conflicts and to remove any threats to peace and security. The UN Charter (1945) highlights that member states agreed that, for any dispute seen as endangering the maintenance of international peace and security, states must first seek a durable solution by negotiation, enquiry, mediation, conciliation, arbitration, and judicial settlement.

The UN Secretary-General, Dag Hammarskjöld, coined the idea of orthodox preventive diplomacy. Ackermann (2003:340) states that, during Dag Hammarskjöld's leadership, the theory and practice of orthodox preventive diplomacy was expressed in the determination of, "keeping regional conflicts localised so as to prevent their spill-over into the superpower arena".

Ramcharan (2008:2) contends that Dag Hammarskjöld often relied on orthodox preventive diplomacy, sending diplomats on special missions in challenging situations. In his ambition of resolving and preventing the recurrence of atrocities between and among states, his approach of orthodox preventive diplomacy was both operational and structural.

His successor as UN Secretary-General, $U$ Thant, took this vision of orthodox preventive diplomacy forward. During his term, orthodox preventive diplomacy made significant contributions in addressing disputes between states and preventing humanitarian crises (Ramcharan 2008:2). As an example, through the use of orthodox preventive diplomacy, $U$ Thant succeeded in stopping the Cuban missile crisis between the United States of America and the Soviet Union turning into nuclear war. During $U$ Thant's leadership, orthodox preventive diplomacy became a vital mechanism applied, not only to alleviate human suffering, but also to prevent any probability of war. He therefore pleaded for attention to ways in which the UN peace and security framework should apply orthodox preventive diplomacy to address and prevent violent conflicts and any other humanitarian crises (Ramcharan 2008:3). 
A later UN Secretary-General, Javier Pérez de Cuellar, continued the concept of orthodox preventive diplomacy. It can be argued that because De Cuellar had strong diplomatic skills and professionalism, he was able to stop the long war (1980-1988) between Iran and Iraq from developing into a wider regional war (Ramcharan 2008:4). Through the use of orthodox preventive diplomacy, he tried to resolve the dispute between Argentina and the United Kingdom over the Falkland/Malvinas Islands, though eventually there was war. He also helped Bulgaria and Turkey in 1989 to resolve their dispute through orthodox preventive diplomacy in the form of mediation. Moreover, he contributed much to the concept of orthodox preventive diplomacy by calling upon UN member states to establish mechanisms to help detect any threats to peace and security between states and to address them before they resulted in wars (Ramcharan 2008:4).

The UN Secretary-General, Boutros Boutros-Ghali, took office shortly after the end of the Cold War when the dramatic change from interstate to intrastate wars became more obvious. In January 1992, he wrote a famous report on the UN's role in maintaining international peace and security. In this report, the concept of orthodox preventive diplomacy was expanded to include conflict prevention, peacemaking, and peacekeeping. It was in this report that the first working definition of orthodox preventive diplomacy was coined. Boutros-Ghali made orthodox preventive diplomacy a priority in cases of violent conflict across the globe. During the border dispute between Eritrea and Yemen, and especially in major conflicts in the former Yugoslavia, he relied on orthodox preventive diplomacy, which in the former Yugoslavia involved UN peacekeeping troops to help contain conflict (Ramcharan 2008:4).

During the time of Boutros-Ghali, two different scenarios occurred. Initially, the idea of orthodox preventive diplomacy originated during the period in which conflicts were largely between states; this period lasted into the Cold War era. Conflicts in the former Yugoslavia, and Somalia marked the start of the second scenario, in which conflicts have been mostly within states. This changing character of war and warriors is one of the reasons why Boutros-Ghali in his orthodox preventive diplomacy strategies failed to prevent and head off the ethnic conflicts in Rwanda and in Bosnia, which resulted in ethnic cleansing. Jentleson (1996:10) confirms that in the Rwandan case, orthodox preventive diplomacy was seen to be inadequate and less appropriate. However, Jentleson fails to explain possible reasons that led to the concept becoming less effective in the post-Cold War era.

The next Secretary-General, Kofi Annan, took this concept of orthodox preventive diplomacy forward and accentuated the role of preventive activities during his leadership. He submitted three reports on orthodox preventive diplomacy, the last of which divided preventive actions into three categories: structural, operational and systemic measures (Ramcharan 2008:4). Ramcharan (2008:9-10) further argues that Kofi's first success came when he applied 
orthodox preventive diplomacy to the border dispute between Cameroon and Nigeria over the Bakassi Peninsula. It is good to note that the success was obvious, because the dispute was between Nigeria and Cameroon and it was actually an interstate dispute. Ackermann (2003:341-347) argues that Kofi Annan's leadership boosted the UN's efforts to maintain international peace and security through orthodox preventive diplomacy by transforming the institution's culture from one of reaction to a culture of prevention.

In the Report of the Secretary-General, Preventive diplomacy: Delivering results, Ban Ki-moon (2011), strongly appealed to UN state members, international non-state actors and all stakeholders to make orthodox preventive diplomacy a priority. He argues that states and non-state actors should understand the contributions of orthodox preventive diplomacy in preventing violent conflicts. He urges them to prioritise orthodox preventive diplomacy and to ensure that people's voices are echoed in governance, peace and security. He also insists that UN member states should recognise the significance of orthodox preventive diplomacy in preventing violent conflicts resulting from climate change and global warming.

It is important to know that with the establishment of the Organisation of African Unity (OAU) in the 1960s, and later the formation of the African Union (AU) in 2000, member states made the concept of preventive diplomacy a cornerstone (Amoo 1992:1-2). Both the OAU and AU established commissions of inquiry, mediation, and arbitration to peacefully deal with African conflicts and prevent their recurrence in the future. However, given that the world is experiencing a paradigm shift from old wars (interstate wars) and old soldiers to new wars (intrastate wars) and new soldiers, Ban Ki-moon, the AU and the current literature have not paid attention to the gaps and missing link within the concept of orthodox preventive diplomacy that renders it less appropriate in the cases of African conflicts. Instead, the African conflicts have become prevalent, thus posing tremendous threats to international peace and security. It is, therefore, the purpose of the second section to assess the existent missing link that renders the orthodox preventive diplomacy ineffective in this era of intrastate conflicts, particularly in Africa.

\section{PREVENTIVE DIPLOMACY: THE MISSING LINK}

It was argued in the first section that the concept of orthodox preventive diplomacy developed during the period of interstate conflicts in a bid to limit the outbreak of violence and to prevent it from re-emerging between states. However, after the post-Cold War period, the prevailing character of war changed from interstate to intrastate, though the latter had existed before. The current literature on orthodox preventive diplomacy contains a discouraging record of failures and catastrophes. Some scholars, like Stedman (1995), have argued that the concept of orthodox preventive diplomacy is unable to resolve 
or prevent internal conflicts. Woocher (2009:4) argues that orthodox preventive diplomacy is still an ideal, rather than a reality. A 2004 UN report states that orthodox preventive diplomacy techniques have failed to stop or prevent the outbreaks of intrastate wars which characterise the post-Cold War era. The UN report, A more secure world: Our shared responsibility (2004:100-103) makes it clear that the concept is more relevant when applied to interstate war cases, and less appropriate to intercommunal conflicts in Africa.

Consequently, the nature of war has changed dramatically; the major conflicts threatening international peace and security are within the state. Furthermore, the parties involved in the conflicts, the warriors, the agents and the conflicting parties have all changed (Ozcelik 2005:103). For example, the nature of African conflicts today is not that of a state fighting against another state, but of a community fighting against another community within a state. This was the case in Kenya during the 2007/2008 post-election violence, in which many people lost their lives. Moreover, it was the same case in Rwanda prior to the genocide in 1994, in Zimbabwe during the 2008 post-election violence, in Madagascar, Côte d'Ivoire, and in the Arab Spring which engulfed almost the entire northern Africa, and it is similar in the on-going political unrest in Burundi that continues to claim the lives of many people.

As argued by Ackermann (2003:342-347), preventing the outbreak of destructive conflict within the state remains one of the most difficult challenges of the $21^{\text {st }}$ century. In normal life, it is strongly argued that prevention is better than cure. The same applies to conflict; it is better to act before the crisis occurs than to react when it has already occurred. Though orthodox preventive diplomacy is the backbone of the UN in its bid to maintain international peace and security, it has unfortunately failed to offer enough hope of peace and security in the post-Cold War era, especially in Africa. The task that emerges is to understand the nature of orthodox preventive diplomacy and to uncover the missing link entrenched within the concept that has made conflict resolution and management of the African conflicts an ideal, rather than a reality in the postCold War era.

\section{NATURE OF ORTHODOX PREVENTIVE DIPLOMACY AND ITS MISSING LINKS}

The task of resolving and preventing African conflicts presents many complex challenges to the $A U$ and the international community. Today's literature on peace and security studies shows that scholars and diplomats put a lot of effort into studying the causes of wars and how wars are fought, rather than how they are prevented (Lund 1996:3). In order to understand the missing links and gaps, it is important to understand the nature of orthodox preventive diplomacy by analysing its existent meaning, as defined by the current literature. Firstly, an 
understanding of the meaning of diplomacy is important. In his analysis, Swart (2008:57) argues that diplomacy means the process of preserving peace and security in the global system through communication, mediation, negotiation and representation. He further argues that diplomacy is related to the effort to manage and to generate order within a system of world politics, the purpose being to stop conflicts and prevent them from escalating into wars. In this light, any diplomacy is meant to maintain peace and security, help stop conflicts from spreading, and preventing the recurrence of the same conflicts in future.

So, what is the nature of orthodox preventive diplomacy? In 1992 BoutrosGhali, (1992:18) then Secretary-General of the UN, defined preventive diplomacy as, "any action taken to prevent disputes from arising between parties, to prevent existing disputes from escalating into conflicts and to limit the spread of the latter when they occur". This was immediately after the end of the Cold War when Boutros-Ghali's intention and purpose was to help prevent conflict, and to create a new global world peace. Undoubtedly, the UN was formed to prevent wars and, in reality, to conduct preventive diplomacy (Djibom 2008:14). As confirmed in Article 1(1) of the UN Charter (1945), the first purpose of the UN is to maintain international peace and security, and to that end, "to take effective collective measures for the prevention and removal of threats to the peace, and for the suppression of acts of aggression or other breaches of the peace, and to bring about by peaceful means, and in conformity with the principles of justice and international law, adjustment or settlement of international disputes or situations which might lead to a breach of the peace".

Moreover, it is also stipulated in Chapter VI, Article 33 and Chapter VII, Articles 39, 40 and 41 of the UN Charter (1945) that parties should seek a solution to their disputes through peaceful means. The United Nations report, A more secure world: Our shared responsibility (2004:100-1003) illustrates that, should disputes fail to reach a consensus through peaceful means, the Charter allows the UN Security Council to determine any military force known as peacekeeping or preventive's deployment in an area when conflicts have erupted.

However, Boutros-Ghali's definition of orthodox preventive diplomacy suffers from a lot of ambiguity, in the sense that the latter clause seems to be opposing the former. It confuses prevention with containment (Djibom 2008:14). In the current new wars within the state, like the ethnic conflict seen in Rwanda in 1990-1994, this understanding and approach of orthodox preventive diplomacy was not sufficient; and so the concept became less appropriate.

Lund (1996:37) defines orthodox preventive diplomacy as, "actions taken in vulnerable places and times to avoid the threat or use of armed force and related forms of coercion by states or groups to settle the political disputes that can arise from the destabilizing effects of economic, social, political, and international change". 
This definition sounds too much like conflict management in the sense that it refers to the settlement of open conflicts or already ongoing conflicts. Another weakness of this definition is that it refers to suppression of an open conflict and fails to address it from the root causes. This understanding and approach therefore fails to prevent the re-emergence of violence.

Equally, both these definitions of orthodox preventive diplomacy fail to recognise the character of new wars and warriors. In the case of Rwanda in 1994, prior to the genocide, orthodox preventive diplomacy in the form of mediation was underway in Arusha, Tanzania between the government and the leaders of the opposition Rwandan Patriotic Front (RPF). In this case, orthodox preventive diplomacy was viewed to be less appropriate for two reasons. The first reason is that peace practitioners and mediators failed to understand the nature of the Rwanda conflict. Thus, the orthodox preventive diplomacy, as applied during the mediation process, did not recognise the importance of including the local community in the entire process. The second is that the venue where orthodox preventive diplomacy was taking place was very far from the people; so their voices were neither heard, nor echoed. This remoteness denied local people the opportunity to send their representatives to speak on their behalf in the process. As a result of this exclusion from the process and the remoteness of the place where the orthodox preventive diplomacy took place, genocide was unleashed when the then Rwandan president perished when his aircraft was shot down during April 1994.

Furthermore, orthodox preventive diplomacy does not tackle the root cause of conflicts. It does not lay down a roadmap for peace which goes beyond the negotiating table, to be followed step by step when the peace agreement is implemented. In this light, Boutros-Ghali's and Michael Lund's definitions do not involve all agents in the process of preventing conflict, as their approaches exclude grassroots people, such as local Community-Based Organisations (CBOs). Their approaches involve only top level leaders, forgetting that in African conflicts, like ethnic-based conflicts, these top leaders are hardly affected by the violence, and may have little idea of who the warrior is and where the warrior lives. It is important to understand that leaders in Africa lack responsiveness and accountability. Another weakness of these definitions is that they fail to include middle range leaders, such as local Non-Governmental Organisations (NGOs), who are most affected by the ethnic-based and intercommunal conflicts. These middle range leaders are often the uniting factor between the grassroots people and the top level leaders. They, therefore, play a vital role in the practice of preventive diplomacy efforts in Africa. To involve them in the process would help ensure the success of preventive diplomacy on the continent.

Given that the character of wars has changed, the above definitions become unsuited in tackling and preventing new wars in Africa by dealing with their root causes. As confirmed by Tripodi and Wolfendale (2011:26-45), these 
new wars are depicted as involving, besides state forces, non-state and irregular forces and state-recruited irregular armies. These latter agents in the new wars come from the local communities. They include insurgent groups, criminal gangs, diaspora groups, ethnic parties and mercenaries, as well as irregular armies. Irregular forces such as guerrillas, insurgency groups and terrorists mostly target civilian populations directly or indirectly within the communities through such tactics as ethnic cleansing attacks, terrorist attacks, hostage taking, systematic rape, hiding among civilian populations and the use of human shields (Tripoli and Wolfendale 2011:71). This confirms that warriors in the new wars are hosted by the communities and any preventive diplomacy effort should involve the grassroots level or local community in the process. This, therefore, makes Boutros-Ghali's and Michael Lund's definitions of orthodox preventive diplomacy less appropriate. Cahill (2000:31) notes that this is why orthodox preventive diplomacy is experiencing failure. There is a need for a paradigm shift with regard to preventive diplomacy and approaches, in order to fill the gaps left by BoutrosGhali's and Lund's definitions, making new preventive diplomacy appropriate in addressing security threats in Africa.

Additionally, to make preventive diplomacy a reality in this era of intrastate conflicts in Africa, a more practical approach is much needed, but this should also be flexible enough to be applicable to different contexts. As Eskandarpour and Wennmann (2011:3) point out, effective preventive diplomacy should be based on an in-depth contextual analysis and rooted within collaboration between state and local community agents. This means that, as the character of war is changing, for preventive diplomacy to be realistic, the definition of the new preventive diplomacy must involve all agents; there must be a strong coalition between the government and the local people in the process. It is essential to argue that such coalitions are crucial to build confidence and to establish early warning mechanisms which can help to prevent the relapse into violence. Hence, the third section entails a working definition of the new preventive diplomacy and an explanation of its components that will make the concept work effectively in the resolution and prevention of African conflicts in the post-Cold War era.

\section{DEFINING THE NEW PREVENTIVE DIPLOMACY}

The emerging concern is to formulate an inclusive definition of new preventive diplomacy which will be applicable to situations of ethnic-based and intercommunal violent conflicts in Africa. In this regard, the definition of new preventive diplomacy spelled out in the Council for Security Cooperation in the Asia Pacific (CSCAP) and Confidence and Security Building Measures (CSBM) International Working Group Report, Preventive diplomacy: Charting a course for the ASEAN Regional Forum (2002), can be used. This definition states that new preventive diplomacy refers to a set of non-coercive activities and actions that involve all 
agents at grassroots, middle-range and top-range leadership levels, carried out in vulnerable places by individuals, governments, civil society, and transnational and international agencies, through willingness and consent of all parties directly or indirectly involved, to prevent looming disputes arising between/among parties from escalating into violence, and to identify and address the underlying causes of existing conflicts. It should be understood that this definition embraces all the agents in the process of preventing both latent and open conflict. It involves private individuals, as well as national and international civil society organisations in the process of addressing violent conflicts and preventing their recurrence.

Latifi argues that the main focus of the new preventive diplomacy is to identify and respond to looming conflicts in order to prevent the eruption of violence. The new preventive diplomacy must occur at all levels in the community; nationally, regionally and internationally. In this light, for any preventive diplomacy effort to be successful in resolving African conflicts and to lead to sustainable peace in Africa, whether working from the bottom- up or top-down to prevent and resolve conflicts, it must recognise the contributions of civilians at the grassroots level.

\subsection{Nature of the new preventive diplomacy}

The new preventive diplomacy has been successfully applied to different cases of internal conflict on the continent of Africa. It was successfully applied in Kenya and Zimbabwe in 2008 when electoral conflicts erupted between the ruling party and the opposition. The UN sent peacekeeping forces into Liberia and the Democratic Republic of Congo in 2003 to contain the ethnic conflict (Wallensteen and Moller 2003:3). It is clear that, while the conflict was contained, the UN peacekeepers failed to tackle the root causes that led to conflict. Wallensteen and Moller furthermore point out that during 2004, the UN Security Council threatened to apply targeted sanctions in two cases, Sudan and Côte d'Ivoire, clearly with the aim of preventing situations from escalating into atrocities.

In these two states it can be understood that, while in Côte d'Ivoire there is no open conflict, in South Sudan conflict recurred. It is essential to know that the new preventive diplomacy, as applied to the above cases, was still not effective. It is argued that the concept was partially applied and implemented. Furthermore, the use of threats and force thwarted its effectiveness. Therefore, the nature of the new preventive diplomacy can be effective when three phases, namely the operational, structural and systemic, are incorporated together. This means that for the new preventive diplomacy to be effective and prevent the recurrence of conflicts, the three phases must be simultaneously implemented to the letter. 


\subsection{Operational phase}

The operational phase of new preventive diplomacy is mostly useful once the conflict or violence has started. It may take different forms, such as diplomatic denunciations, mediation, imposing either economic or smart sanctions, providing good offices, peacekeeping, diplomatic protests, active monitoring, and other forms of third-party intervention (Wallensteen and Moller 2003:3). As argued by Gow and Dandeka (1997:327-348), when the new preventive diplomacy takes the form of peacekeeping, the goal is to contain conflict, to limit the effects of conflict, and to help parties settle their disputes. In other words, this form of new preventive diplomacy through peacekeeping helps open a window for mediation and negotiation to take place.

In Kenya, during the post-election violence of $2007 / 2008$, the operational phase of new preventive diplomacy took the form of mediation. The mediation was led by the AU under the chief mediator, Kofi Annan, and it took place between the ruling Party of National Unity (PNU) and the opposition Orange Democratic Movement (ODM). It stopped the conflict at an early stage before it could engulf the entire country and it appealed to Kenyan citizens to find solutions to their problems through negotiations. The operational phase, as the short-term new preventive diplomacy, is not sufficient on its own. It has to be succeeded by the structural phase which addresses the root causes of the conflict in order to prevent a future recurrence of conflict.

\subsection{Structural phase}

The structural phase of new preventive diplomacy complements the operational one. It takes the operational phase further to prevent the recurrence of conflict. Wallensteen and Moller (2003:3) argue that the structural phase of new preventive diplomacy implies a long-term assessment of a particular conflict to understand its root causes and to tackle them. The Carnegie Commission's Report, Preventing deadly conflicts (1997), also argues that the structural phase of new preventive diplomacy comprises strategies to address the root causes of deadly conflict to ensure that crises are prevented or, if they occur, they do not recur. The same report argues that strategies in the structural phase include putting in place legitimate systems that equally meet people's basic economic, social, cultural, and humanitarian needs.

The structural phase of new preventive diplomacy requires addressing the deepest roots of conflict. Jentleson (1996:3-5) finds that a comprehensive structural phase must first focus on the underlying political, social, economic and environmental causes of conflict. This is what the Carnegie Commission's Report calls structural prevention, addressing the root causes of deadly conflicts, as differentiated from operational prevention which is undertaken to stop the imminent violence. For example, in the Kenyan case, the negotiations led to 
structural reform which brought about a new constitution. The new constitution, in turn, initiated critical judicial and police reforms. These reforms played an important role in curbing the recurrence of post-election violence during the 2013 general elections in Kenya. Raila Odinga, a presidential candidate on a Coalition for Reform and Democracy (CORD) ticket, who had lost the general elections, trusted the judicial system in place and chose to register his discontent with the high court of Kenya. This was in opposition to the 2007 general elections that led to post-election violence.

\subsection{Systemic phase}

This third phase of the new preventive diplomacy was introduced for the first time by Kofi Annan in 2006. In his report, Progress of armed conflict (2006:5), he refers to new preventive diplomacy as the measures taken at the global level to address and prevent any threats to peace and security that transcend the ability and capacity of particular states. This phase is more concerned with threats that transcend boundaries and endanger international peace and security, and can only be handled through collective mechanisms at the regional or international level. The UN report, A more secure world: Our shared responsibility (2004:76-88) explains that such threats include poverty; nuclear, radiological, chemical and biological weapons; international terrorism; transnational organised crime; drug trafficking, money laundering, infectious diseases; environmental degradation and pollution; and prosecution of war crimes.

\section{COMPONENTS OF NEW PREVENTIVE DIPLOMACY}

In the periods before and during the Cold War, the threats to international peace and security were considered real only when they came from one's enemy, and that enemy had to be powerful. Today, the threats to international peace and security have changed. They emanate not only from the enemy, but also from the associate; not only from the powerful states, but also from the weak ones. The weakness of the global South is a threat to all (Cahill 2000:35). In the UN report, A more secure world: Our shared responsibility (2004:76-77), it also highlights that a threat to one state becomes a threat to all. What is clear, is that insecurity in Africa threatens the security of the global North (Cahill 2000:35). In order to understand the significance of addressing and preventing ethnic violence in Africa, peace practitioners and scholars of diplomacy need to understand the components or vectors of the new preventive diplomacy.

The vectors that make new preventive diplomacy sustainable and successful in Africa include sustainable economic development, human rights promotion, democratic governance and education. Cahill (2000:35) argues that new preventive diplomacy should begin with efforts to generate economic 
development and to promote significant progress in instruction, education, human rights, and the training of women and men as citizens. In a real sense no tree can stand, nor withstand a heavy wind without having its roots firmly rooted in the soil. The same applies to new preventive diplomacy. The concept cannot stand and help prevent conflicts involving ethnic-based and intercommunal violence without having its roots firmly entrenched in equal access to opportunities in development, education, respect for people's rights, justice and democratic governance.

\subsection{New preventive diplomacy to promote sustainable economic development}

It is well documented that there can be no peace without development and vice versa. Cahill (2000:35) finds that development is the new name for peace and a factor for peace. Somavia (2015) states that there can be no peace without development, as insecurity and violence feed on poverty, injustice and inequalities. Therefore, it can be confirmed that poverty and social injustice breed violence and conflicts. In this sense, the new preventive diplomacy must establish systems and/or structures that address the uneven opportunities in economic development.

Underdevelopment and unemployment in Africa fuel African conflicts and make them intractable. These conflicts not only pose major threats to Africa, but also to international peace and security (Cahill 2000:36). For instance, in Kenya, youth unemployment is one of the major factors that lead to many young people joining the Al-Shabab movement in neighbouring Somalia. This movement has posed security threats to the whole Eastern Africa Region and the Indian Ocean Region, as well as to the global world. Somavia (2015) argues that employment and income generation are fundamental elements of any preventive diplomacy effort. For societies, communities and individuals, getting a job and a regular income provide the means for survival. In sum, generating employment and equal access to economic development are the important mechanisms that make new preventive diplomacy sustainable.

\subsection{New preventive diplomacy to promote human rights}

In Africa, human rights violation poses a major threat to international peace and security at present. It is important to argue that the majority of African leaders are human rights violators, and some ascended to power through the blood-shed of innocent people. In many regimes in Africa openness, responsiveness, the rule of law and equal justice is a language that leaders do not want to understand. Cahill (2000:42) says that there is an indissoluble link between violence and the violation of human rights and, at the same time, there is a definite equation between peace and the observance of human rights. 
The Carnegie Commission's Report $(1997: 7,21)$ finds that rampant human rights abuses are often the prelude to violence. Human rights violations reflect a breakdown in the rule of law and justice, and if they are left unchecked, the result will be the reinforcement of lawlessness in which people will take matters into their own hands. Human rights promotion in this sense is very significant, not only as a moral imperative, but also as a mechanism of analysis and policy formation, with violation serving as an early warning of a possible conflict and violence. Ramcharan (2000:500) states that the rule of law and the role of local and international courts in upholding and promoting people's rights are to help prevent the recurrence of conflicts. Therefore, the respect and promotion of human rights is a strong rationale for new preventive diplomacy to be sustainable and to help prevent the recurrence of conflicts in Africa (Carnegie Commission Report 1997:7).

\subsection{New preventive diplomacy to promote democratic governance}

In many cases African conflicts arise as a result of a lack of democratic governance and strong institutions. However, owing to uneven and weak institutions, democratic governance in many cases in Africa propagates political violence, rather than promoting peace and security. Fareed (1997:22-43) finds that democratic elections in a country which does not have even and strong institutions create "illiberal democracies" that pose threats to peace and security among ethnic communities.

Nevertheless, the Carnegie Commission's Report (1997:7) states, there is possibly no more fundamental political right than the ability to have a say in how one is governed. Democratic governance built on strong institutions reflects a shared contract between the leaders and the governed; it ensures the ability to be free from fear and want. Thus, democratic governance built on equal and strong institutions stands as an important backbone to sustaining new preventive diplomacy. The concept becomes a strong pillar that helps to successfully resolve and prevent conflicts in Africa.

\subsection{New preventive diplomacy to promote education}

It is consequently confirmed that education is the key to new preventive diplomacy. Cahill $(2000: 40,42)$ notes that illiteracy is the source of internal and external tensions that may lead to violent conflicts. He further states that knowledge is the key to social progress, and education is the principal vector of knowledge. High levels of illiteracy in Africa pose a threat to peace and security. Unawareness caused by illiteracy results in people failing to understand and rightly defend their rights, not being able to read and understand early signs of conflicts, or to know how to peacefully deal with conflicts when they occur. It is important to note that education gives awareness, and if people are aware, the 
levels of crime (both organised crime and crimes against humanity) decrease. Therefore, the new preventive diplomacy finds its strength in promoting equal opportunities in education. Cahill (2000:41) argues that education is the best form of new preventive diplomacy, and the most powerful tool to promote peace and security.

\section{CONCLUSION}

Today new threats to international peace and security emanate from weak and failing governments, fragile institutions, paramilitary groups, local warlords, criminal gangs, police forces, mercenary groups, terrorism groups, religious fundamentalists and breakaway units from regular armies (Beeson and Bisley 2010:130). For conflict prevention to be successful in dealing with African conflicts and to prevent their recurrence, the need for a paradigm shift from orthodox preventive diplomacy to new preventive diplomacy, as witnessed in the Kenyan case, becomes inevitable.

As discussed in this article, orthodox preventive diplomacy evolved during the time when conflicts occurred between and/or among states. In other words, the concept was developed when conflicts that were posing threats to international peace and security were interstate in nature. It was noted that balance of power, the establishment of laws of war and the upholding of customary and international laws, as well as the establishment of judicial systems, arbitration and mediation, played a major role in resolving and preventing conflicts between and among states. However, when the Cold War ended, the nature and character of conflicts changed from that of interstate to intrastate. This made the African continent suffer from intercommunal and ethnic-based conflicts that continued to pose threats to both national and international peace and security. In this article, it is argued that the prevalence of African conflicts is a clear indication that orthodox preventive diplomacy, as applied by the AU peace practitioners and mediators, has become ineffective.

Therefore, the new preventive diplomacy has a significant role to play in resolving and preventing African conflicts. Unquestionably, it can help to stop existing violent conflicts and inhibit the re-emergence of violence, as was seen in its application in Kenya in 2008. It not only stopped the existent violent conflict, but eventually prevented the recurrence of ethnic-based conflict in the 2013 general elections. The role of the new preventive diplomacy in violent conflicts in Africa is twofold. Firstly, it stops the outbreak of disputes before they turn into violence. Secondly, it helps address the root causes of the conflict by tackling the security threats embedded in the structures, systems, institutions, economy and culture which constitute a state. In other words, the new preventive diplomacy helps build strong institutions that allow for good governance. Swart (2008:59) argues that the new preventive diplomacy is very significant because its preventive activities 
mostly extend along the entire spectrum of conflict, from the latent stage through the culmination and resolution of conflict to post-conflict peace building.

Thus, it is asserted that in Africa, and any other place where people suffer from structural and open violence, and intercommunal conflicts, there is a need for a paradigm shift from orthodox preventive diplomacy to the new preventive diplomacy in conflict management and prevention. The new preventive diplomacy plays a vital role in preventing the emergence and re-emergence of violent conflicts, and diminishes the likelihood of ongoing disputes from spilling over into deadly wars. Therefore, the new preventive diplomacy should be seen and promoted as a valuable remedy that can be used to help the prevention of African conflicts.

\section{LIST OF SOURCES}

Ackermann, A 2003. "The idea and practice of conflict prevention", Journal of Peace Research 40(3):340-347, https://doi.org/10.1177/0022343303040003006

Amoo SG 1992. "The OAU and African conflicts: Past successes, present paralysis and future perspectives", Institute of Conflict Analysis and Resolution, <http://scar.gmu. edu/wp_5_amoo.pdf>, accessed 12 January 2016.

Annan, K 1999. Facing the humanitarian challenge: Towards a culture of prevention. New York: United Nations.

Annan, K 2005. "In larger freedom: Towards development, security and human rights for all". Report of the Secretary General. UN Document A/59/2005. New York: United Nations.

Annan, K 2006. "Progress Report of Armed Conflict". United Nations Report A/60/891. New York: United Nations.

Beeson, M and N Bisley 2010. Issues in 21 ${ }^{\text {st }}$ century world politics. Basingstoke: Palgrave Macmillan.

Boutros-Ghali, Boutros 1992. "Agenda for peace: Preventive diplomacy, peacemaking and Peacekeeping". Report of the Secretary-General A/47/277-S/ 24111. New York: United Nations.

Branislav, LS 2005. "Territory and commitment: The Concert of Europe as self-enforcing equilibrium", Security Studies Journal 14(4), October-December 2005:565-606, https://doi.org/10.1080/09636410500468792

Cahill, MK 2000. Preventive diplomacy: Stopping wars before they start. New York: Routledge. 
Carnegie Commission on Preventing Deadly Conflict 1997. Final Report, <http:// www. insightonconflict.org/wp-content/uploads/2013/07/Carnegie-Commission _ Summary.pdf>, accessed 25 February 2015.

Council for Security Cooperation in the Asia Pacific (CSCAP) and Confidence and Security Building Measures (CSBM) International Working Group 2002. "Report: Preventive diplomacy: Charting a course for the ASEAN Regional Forum", Issues and Insights 3-02, <http://csis.org/files/media/csis/pubs/issuesinsights_v02n03. pdf>, accessed 12 December 2014.

Djibom, J 2008. "An analysis of Hammarskjold's theory of preventive diplomacy", Peace Operations Training Institute 2008, <http://media.peaceopstraining.org/ theses/ djibom.html>.

Elrod, R 1976. "The Concert of Europe: A fresh look at an international system", World Politics 28(2):159-174, https://doi.org/10.2307/2009888

Eskandarpour, A and A Wennmann 2011. Strengthening preventive diplomacy: The role of private actors. Centre on Conflict, Development and Peacebuilding (CCDP), Geneva, <http://www.gpplatform.ch/strengthening-preventive-diplomacy-role-privateactors>, accessed 21 March 2013.

Falk, R and SH Mendlovitz 1996. The United Nations: The strategy of world order. New York: World Law Fund.

Fareed Z 1997. "The rise of illiberal democracy", Foreign Affairs 76(6):22-43, https://doi.org/10.2307/20048274

Gow, J and C Dandeka 1997. "The future of peace support operations: Strategic peacekeeping and success", Armed Forces \& Society 23, Spring:327-347.

Higgins, P 2014. The Hague Peace Conferences and other international conferences concerning the laws and usages of war. Texts of Conventions with Commentaries. Cambridge: Cambridge University Press.

Holbraad, C 1971. The Concert of Europe: A study in German and British international theory 1815-1914. London: Longman.

Jentleson, B 1996. "Preventive diplomacy and ethnic conflict: Possible, difficult, necessary", <http://igcc.ucsd.edu/assets/001/501212.pdf>, accessed 22 March 2015.

Jentleson, B (ed.) 2000. Opportunities missed, opportunities seized: Preventive diplomacy in the post-Cold War. New York: Carnegie Commission. 
Eric Niyitunga - Assessing the missing link within the concept of preventive diplomacy

Kaldor, M 2012. New and old wars: Organized violence in a global era. Cambridge: Polity Press.

Lund, M 1996. Preventing violent conflicts: A strategy for preventive diplomacy. Washington, DC: United States Institute of Peace.

Ozcelik, S 2005. "Preventive diplomacy, conflict prevention in the Black Sea Region: The case of the Crimean Tatars", Uluslararasi Hukuk ve politika Cilt 1(4):102-123.

Ramcharan, B 2006. "Contemporary challenges of human rights protection: A call for preventive strategies", Rutgers Law Journal 37(2):495-516.

Ramcharan, B 2008. Preventive diplomacy at the UN. Bloomington: Indiana University Press.

Somavia J 2015. "Employment for peace, stability and development: Regional strategy for Horn of Africa 2011-2015", <http://www.ilo.org/wcmsp5/groups/public/ africa/documents/meetingdocument/wcms_176826.pdf>, accessed 22 March 2015.

Stedman, SJ 1995. "Alchemy for a new world order: Overselling preventive diplomacy", Foreign Affairs (Council on Foreign Relations) 74(3):14-20, https:// doi.org/10.2307/20047119

Swart, GS 2008. "The role of preventive diplomacy in African conflicts: A case study of Democratic Republic of Congo, 1998-2004", <http://repository.up.ac. za/bitstream/handle/2263/24113/dissertation. pdf?sequence=1\&isAllowed=y>, accessed 21 May 2013.

Tripodi, P and J Wolfendale (eds) 2011. New wars and new soldiers: Military ethics in the contemporary world. London: Ashgate.

United Nations n.a. "Charter and the Statute of the International Justice". San Francisco, USA, <https://treaties.un.org/doc/publication/ctc/uncharter.pdf>, accessed 14 June 2015.

United Nations n.a. Report of the High-level Panel on threats, challenges and change. "A more secure world: Our shared responsibility", <http:// www.un.org/en/peacebuilding/pdf/historical/hlp_more_secure_world.pdf.>, accessed 16 February 2015.

United Nations 2011. "Preventive diplomacy: Delivering results". Report of the Secretary-General, <http://www.un.org/wcm/webdav/site/undpa/shared/undpa/pdf/ SG\%20Report\%20on\%20Preventive\%20Diplomacy.pdf>, accessed 13 January 2016. 
Wallensteen P and F Moller 2003. "Conflict prevention: Methodology for knowing the unknown", Uppsala Peace Research Articles 7:3.

Woocher L 2009. Preventing violent conflict: Assessing progress, meeting challenges. Washington DC: United States Institute of Peace. 